\title{
Obama administration report underlines support for biotech
}

The White House released in April a broad plan to encourage growth of bio-based industries, a public acknowledgement of the impact biotech has on the global economy. The 43-page report, called the National Bioeconomy Blueprint (http://www.whitehouse. gov/sites/default/files/microsites/ostp/national_bioeconomy_ blueprint_april_2012.pdf), lays out national strategies to realize the full potential of biotech industries such as drugs, diagnostics, genetically modified crops, biofuels, bio-based chemicals and industrial enzymes. According to the report, "The bioeconomy has emerged as an Obama Administration priority because of its tremendous potential for growth as well as the many other societal benefits it offers."

The blueprint is viewed by many biotech companies as the first presidential endorsement of all the elements of the biotech industry. "It's a very strong signal from the White House saying, 'We recognize the potential of a bio-based economy'," says Adam Monroe, head of the North American division of Novozymes, an enzyme developer headquartered in Bagsvaerd, Denmark. "We hear it from the Department of Agriculture and the Department of Energy but that's not the same pulpit as the president," he says. Industry leaders say the endorsement may help shape public awareness of biotech companies in a positive way. Says Richard Eno, CEO of Metabolix, "It gives us more exposure as a company participating in the bioeconomy."

The blueprint describes five strategic objectives for the bioeconomy. One is to support investment in R\&D, particularly in "key emerging foundational technologies" such as synthetic biology, bioinformatics and proteomics. As an example of progress in this area, the report highlighted the Department of Homeland Security's support of a genomics-based approach to microbial forensic analysis, which will allow identification of any unknown microbial organism. The blueprint's focus on synthetic biology is a confidence boost for companies in that sector which have shied away from the limelight. "Some of those companies are bashful about being public about their technology," because they are unsure how it will be perceived by the public, says Rina Singh, a senior

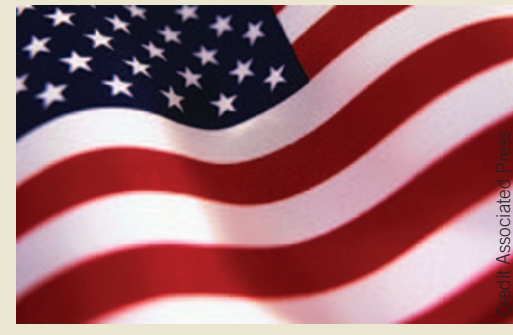

The National Bioeconomy Blueprint will encourage bio-based industries. policy director at the Biotechnology Industry Organization (BIO) in Washington, DC.

The blueprint's second objective is to better move discoveries from the laboratory to the market, including by utilizing federal agencies' authority to give purchasing preference to bio-based products. In coordination with the blueprint, secretary of agriculture Tom Vilsack announced May 1 new guidelines to expand his agency's BioPreferred program.

A third objective is to reduce regulatory barriers. The report noted the US Food and Drug Administration's efforts to involve external experts to help expedite the review of medical devices. Two final objectives are to align education with bioeconomy workforce needs, and to encourage public-private collaborations.

The report mostly lists government programs already underway, and proposes no new specific programs to spur innovation or help the bioeconomy compete with fossil fuels, one of its biggest challenges. Says Singh at BIO, "Congress needs to take the blueprint, work from it, and enact or reauthorize legislation to make it a reality."

The European Commission in February adopted its strategy for a sustainable bioeconomy. The plan focuses on industrial biotech rather than health and medicine.

Emily Waltz Nashville, Tennessee

\section{Around the world in a month}

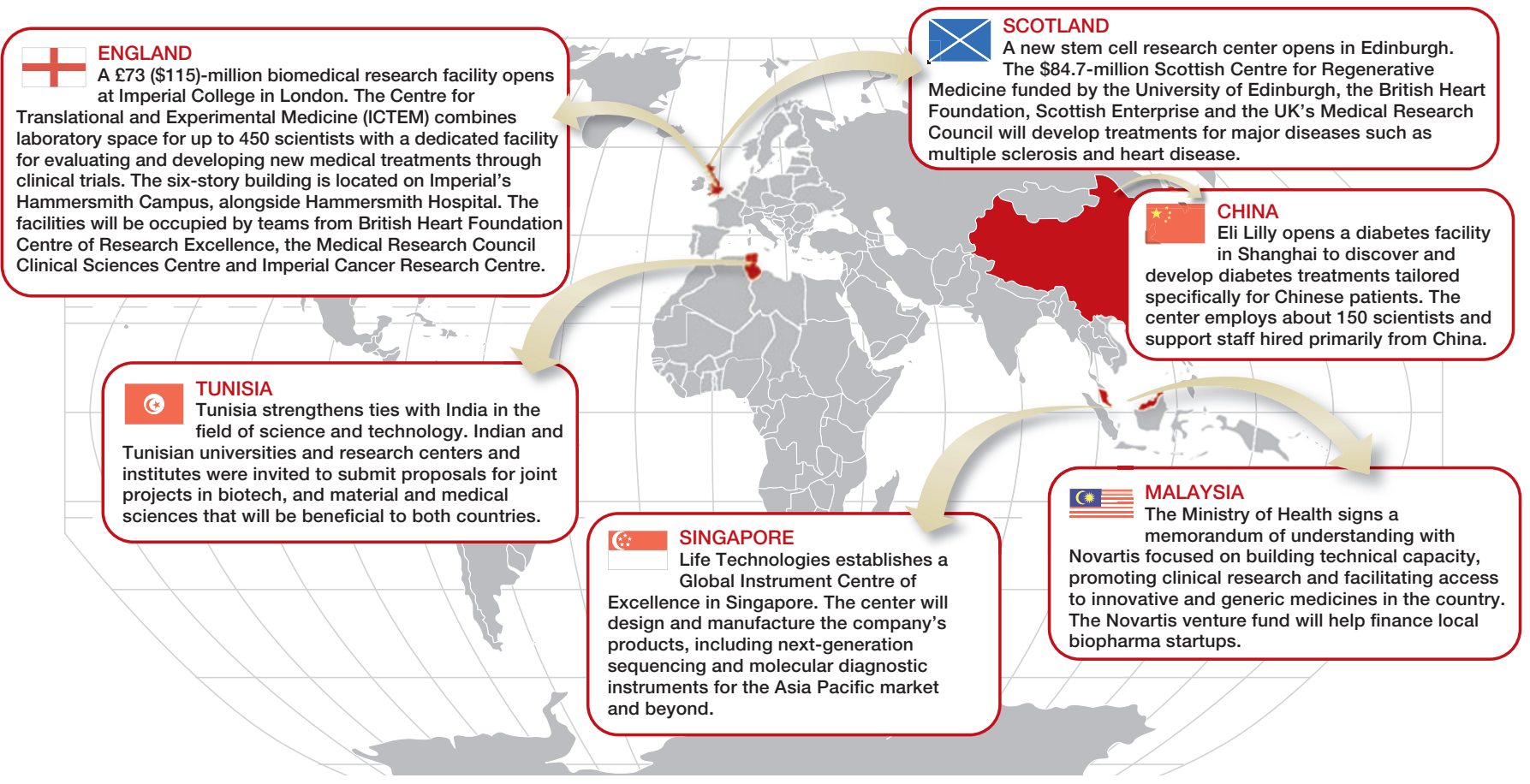

